\title{
PERANCANGAN ZERO VOLTAGE SWITCHING BUCK CONVERTER DENGAN BEBAN RESISTIF BERVARIASI DAN SEBAGAI CATU DAYA UNTUK MOTOR ARUS SEARAH
}

\author{
Zya Jamaluddin Al-Rasyid Arief Rahman*), Jaka Windarta, dan Hermawan \\ Departemen Teknik Elektro, Universitas Diponegoro, Semarang \\ Jl. Prof. Sudharto, SH, kampus UNDIP Tembalang, Semarang 50275, Indonesia \\ *) E-mail : zyajamaluddin@gmail.com
}

\begin{abstract}
Abstrak
Penggunaan konverter arus searah sebagai penghasil tegangan arus searah sudah mengalami perkembangan. Rangkaian konverter arus searah diatur dengan menggunakan rangkaian kontrol Pulse Width Modulation (PWM) yang digunakan sebagai pengendali saklar. Proses ketika saklar mengalami kondisi nyala dan mati mengakibatkan terjadinya rugi-rugi pensaklaran. Masalah tersebut dapat diatasi dengan menggunakan metode soft-switching. Salah satu metode softswitching yang digunakan adalah Zero Voltage Switching (ZVS). Teknik pensaklaran ZVS dapat membuat saklar bekerja ketika tegangan bernilai nol. Teknik pensaklaran tegangan nol ini dapat mengurangi rugi - rugi pensaklaran yang terjadi, sehingga dapat meningkatkan efisiensi konverter arus searah yang digunakan sebagai catu daya motor arus searah. Berdasarkan hasil pengujian, rangkaian konverter arus searah tipe ZVS buck converter dapat menghasilkan daya keluaran sebesar 103,77 watt dengan nilai efisiensi sebesar 94,83\%. Nilai efisiensi tertinggi terjadi ketika diberi beban statis berupa resistor $500 \Omega$ sebesar $99,77 \%$.
\end{abstract}

Kata kunci : motor arus searah, rugi-rugi pensaklaran soft-switching, ZVS Buck Converter

\begin{abstract}
The use of DC-DC converter for make DC voltage nowadays has developed. The DC-DC converter uses electronic component that one of them is the switch, which is controlled by control circuit with Pulse Width Modulation (PWM). The process turn on and off of the switch cause switching power loss. This problem can be solved by using the softswitching tehchnique. One of the soft-switching method that can be used is Zero Voltage Switching (ZVS). This technique lead to zero voltage during switching transition. This technique can decreases the switching losses, so the efficiency DC-DC converter for supply direct current motor can be increased. Based on the test result, ZVS buck coverter can produce power 103,77 watt with the value of efficiency $94,83 \%$. The highest value of efficiency occur when the converter given static load form resistor was $99,77 \%$.
\end{abstract}

Keywords : direct current motor, switching power loss, soft-switching, ZVS Buck Converter

\section{Pendahuluan}

Motor listrik telah mengalami kemajuan yang cukup signifikan. Motor listrik memiliki efisien yang cukup tinggi jika dibandingkan dengan motor konvensional. Salah satu jenis motor yang sering digunakan yaitu motor DC (motor arus searah). Hal ini dikarenakan motor arus searah memiliki keunggulan seperti torsi awal yang besar dan metode pengendalian putarannya sederhana. Pada mulanya, salah satu dengan cara memutar autotrafo. Namun, penggunaan autotrafo memiliki banyak kelemahan salah satunya ditinjau dari segi ekonomis [1].

Salah satu metode alternatif yang dapat digunakan sebagai catu daya motor arus searah adalah dengan menggunakan perangkat elektronika daya. Perangkat elektronika daya yang digunakan dapat berupa penyearah terkontrol (controlled rectifier)[1], [2] maupun menggunakan DC-DC converter ( $d c$ chopper) [3], [4]. Rangkaian konverter arus searah dengan menggunakan rangkaian kontrol Pulse Width Modulation (PWM) beroperasi berdasarkan mode saklar, dimana seluruh arus beban mengalir ketika saklar menyala dan mati selama mode pensaklaran berlangsung. Komponen yang digunakan untuk menjalankan fungsi penghubung tersebut tidak lain adalah saklar yang dapat dikontrol seperti thyristor dan MOSFET[5].

Mode pensaklaran ini dapat menimbulkan rugi-rugi pensaklaran. Salah satu cara meningkatkan efisiensi yaitu dengan cara menggunakan soft-switching sebagai pengganti metode pensaklaran konvensional atau hardswitching yang digunakan. 
Salah satu teknik pensaklaran soft-switching yaitu Zero Voltage Switching (ZVS). ZVS dapat membuat saklar bekerja ketika tegangan bernilai nol. Teknik pensaklaran tegangan nol ini dapat mengurangi rugi - rugi pensaklaran dan meningkatkan efisiensi dari buck converter yang digunakan sebagai catu daya motor arus searah.

Pada Penelitian ini akan dirancang modul perangkat keras konverter arus searah tipe buck dengan mode pensaklaran ZVS dengan beban resistif dan sebagaicatu daya motor arus searah.

\section{Metode}

\subsection{Langkah Penelitian}

Penelitian ini dilakukan dalam beberapa tahap - tahapan yang ditampilkan pada Gambar 1 .

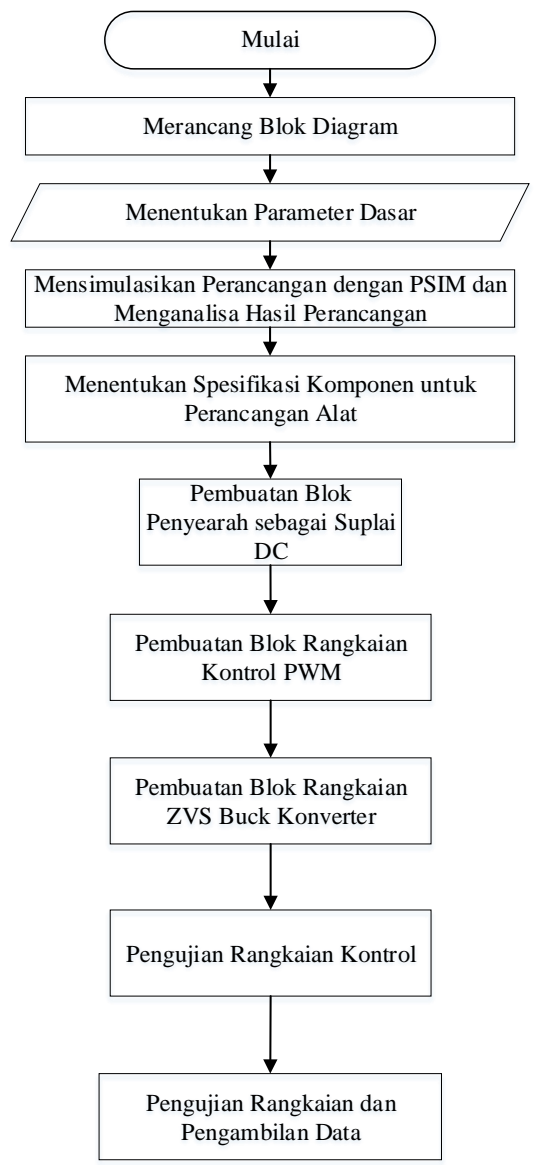

Gambar 1. Flowchart Penelitian

\subsection{Perancangan}

Perancangan alat untuk Penelitian ini terdiri dari rangkaian penyearah (rectifier), rangkaian zero voltage switching buck converter, rangkaian kontrol PWM dan akumulator. Gambar 2 menunjukkan blok diagram alat keseluruhan.

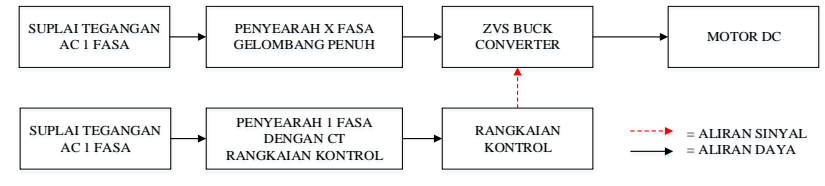

Gambar 2. Blok Diagram Alat

\subsubsection{Penyearah}

Penyearah berfungsi sebagai pengubah sinyal bolak-balik (AC) menjadi sinyal searah (DC). Rangkaian penyearah ini digunakan sebagai suplai daya rangkaian kontrol PWM dan suplai daya konverter arus searah. Gambar 3 menunjukkan rangkaian penyearah dengan trafo center tap (CT) dan Gambar 4 menunjukkan rangkaian penyearah full bridge (jembatan penuh). Penyearah pada Penelitian ini dilengkapi dengan kapasitor sebagai filter tegangan keluaran.

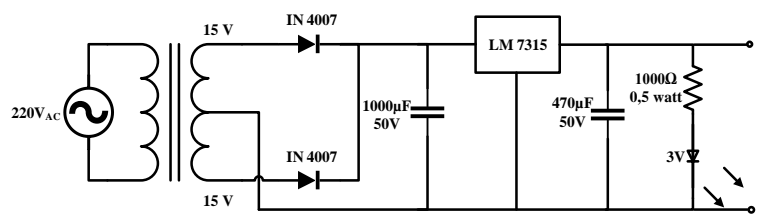

Gambar 3. Rangkaian Penyearah dengan CT

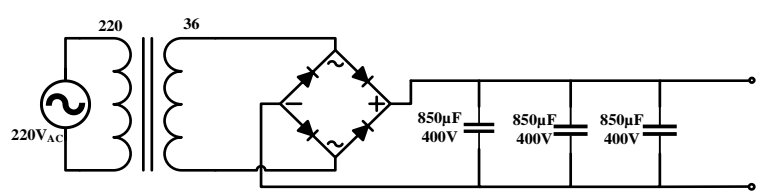

Gambar 4. Rangkaian Penyearah Jembatan Penuh

\subsubsection{Zero Voltage Switching Buck Converter}

Konverter arus searah tipe ZVS Buck Converter digunakan sebagai penyedia tegangan DC sebagai catu daya motor arus searah.

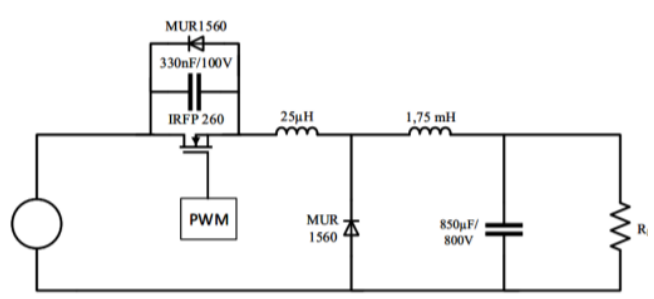

Gambar 5. Rangkaian ZVS Buck Converter

Komponen-komponen penyusun yang digunakan pada konverter arus searah tipe ZVS Buck Converter antara lain:

1. Sumber DC

Sumber DC yang dipakai untuk menyuplai rangkaian konverter arus searah didapat dari rangkaian penyearah. 
Sumber DC ini memberikan tegangan DC sebesar $51 \mathrm{~V}$ untuk mensuplai rangkaian konverter arus searah.

2. Induktor Resonansi dan Kapasitor Resonansi Komponen $\mathrm{C}_{\mathrm{r}}$ dan $\mathrm{L}_{\mathrm{r}}$ dapat dihitung dengan menentukan frekuensi pensaklaran dan frekuensi resonansi dengan syarat berdasarkan Persamaan 1

$f_{o} \geq f_{S}$

dimana

$f_{o}=$ frekuensi resonansi
$f_{s}=$ frekuensi pensaklaran

Pada Penelitian ini frekuensi pensaklaran yang diinginkan adalah sebesar $15 \mathrm{kHz}-45 \mathrm{kHz}$, dan ditetapkan frekuensi resonansi sebesar $55 \mathrm{kHz}$.

Nilai $\mathrm{C}_{\mathrm{r}}$ dan $\mathrm{L}_{\mathrm{r}}$ ditentukan berdasarkan Persamaan 2 berikut

$f_{o}=\frac{1}{2 \pi \sqrt{L_{R} C_{R}}}$

Penentuan kapasitor $\mathrm{C}_{\mathrm{r}}$ disesuaikan dengan kapasitor yang ada di pasaran dan dipilih nilai sebesar $33 \mathrm{nF}$. Dengan mengetahui nilai frekuensi resonansi dan $\mathrm{C}_{\mathrm{r}}$ maka dapat dihitung nilai komponen $\mathrm{L}_{\mathrm{r}}$ menggunakan persamaan (2).

$L_{R}=\frac{1}{\left(2 \pi f_{o}\right)^{2} C_{R}}$

$L_{R}=\frac{1}{(2 \pi \times 55000)^{2} \times 330 \times 10^{-9}}$

$L_{R}=25,374 \mu H$

\section{Saklar}

Pemilihan MOSFET harus mempertimbangkan nilai tegangan dan arus operasi. Tegangan masukan Konverter arus searah adalah 51 volt.

MOSFET yang digunakan adalah MOSFET IRFP260. MOSFET IRFP260 dapat beroperasi pada tegangan maksimal antara drain dan source sebesar 200 volt dan mampu mengalirkan arus hingga 50 ampere[6].

\section{Rangkaian PWM}

Rangkaian PWM digunakan untuk pemicuan MOSFET. Penelitian ini menggunakan IC TL494 sebagai pembangkit PWM. Pada Penelitian ini driver yang digunakan MOSFET driver sebagai penguat sinyal pemicuan untuk MOSFET. MOSFET driver yang digunakan jenis IR2117 yang mempunyai 1 masukan dan 1 keluaran.

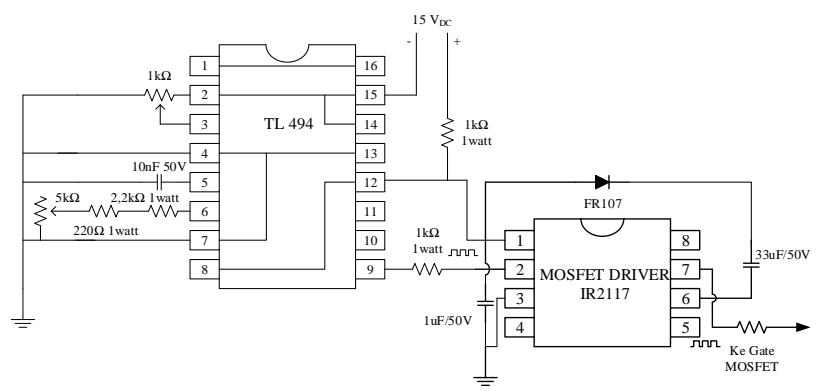

Gambar 6. Rangkaian PWM

Besarnya frekuensi osilasi maksimal dari rangkaian PWM dapat ditentukan dengan persamaan 3 dibawah ini [7]:

$R_{T}=\frac{1,1}{f_{\text {osc }} \cdot C_{T}}$

Besar nilai komponen yang digunakan ialah:

CT : 10nF/50V

$\mathrm{RT}_{\mathrm{Var}}: 5 \mathrm{k} \Omega$

$\mathrm{RT}_{\text {Fix }}: 2200$ dan $220 \Omega / 1 \mathrm{~W}$

$\mathrm{R}_{\mathrm{Var}}: 1 \mathrm{k} \Omega$

Maka, dengan memasukkan nilai resistor dan kapasitor pada Persamaan 3.7 didapat:

$R_{T}=\frac{1,1}{45000 \cdot 10^{-8}}=2.444,44 \Omega\left(\mathrm{R}_{\mathrm{var}}=0 \Omega\right)$

$R_{T}=\frac{1,1}{15000 \cdot 10^{-8}}=7.333,33 \Omega\left(\mathrm{R}_{\mathrm{var}}=5 \mathrm{k} \Omega\right)$

5. Dioda

Dioda yang digunakan adalah MUR 1560. Dioda ini dipilih karena mempunyai sifat ultrafast recovery dengan waktu pemulihan 60ns [8].

6. Tapis Kapasitor dan Induktor

Pada perancangan Penelitian ini, penentuan komponen tapis kapasitor dan induktor adalah dengan dipakai komponen dengan nilai yang relatif cukup besar jika dibandingkan dengan nilai komponen resonansinya. Kapasitor yang digunakan adalah sebesar $850 \mu \mathrm{F} / 450 \mathrm{~V}$ dan Induktor yang digunakan adalah sebesar $1,75 \mathrm{mH}$.

7. Motor Arus Searah

Motor arus yang digunakan pada pengujian Penelitian ini adalah motor arus searah merek dunkenmotoren dengan tipe GR 53x58. Pemilihan merek dan tipe motor arus searah dalam penelitian ini karena motor arus searah teresebut mudah ditemukan dipasaran dan memiliki tegangan kerja sesuai dengan ZVS buck Konverter. 


\section{Hasil dan Analisa}

3.1. Pengujian Rangkaian Konverter Arus Searah 3.1.1. Pengujian Rangkaian PWM

Pengujian rangkaian PWM dilakukan dengan menghubungkan probe osiloskop dengan terminal keluaran rangkaian. Hasil pengujian diperlihatkan pada Gambar 7.

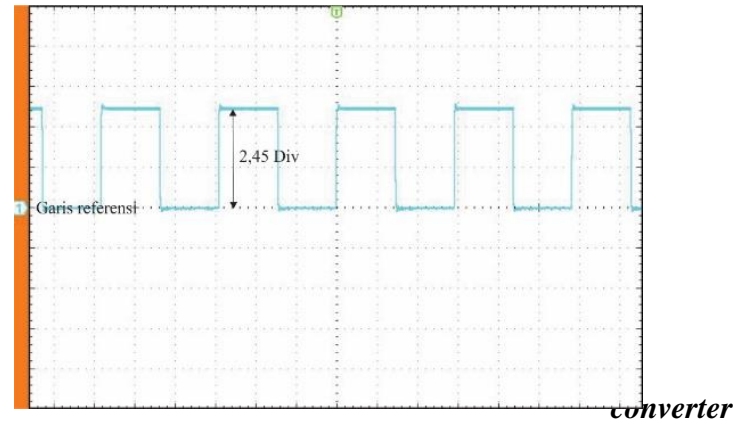

Gambar 7. Gelombang Keluaran Rangkaian Kontrol $(\mathrm{v} / \mathrm{div}=5, \mathrm{~T} / \mathrm{div}=10 \mu \mathrm{s})$

Berdasarkan Gambar 7 diketahui tegangan keluaran rangkaian sebesar 2,9 div dengan skala probe 1X, sehingga nilainya dapat dihitung:

$V_{p p}=2,45 \operatorname{div} \times \frac{5 \mathrm{~V}}{\operatorname{div}} \times 1$

$V_{p p}=12,25 \mathrm{~V}$

Gelombang ini selanjutnya menjadi sinyal pemicuan pada MOSFET.

\subsubsection{Pengujian Mode Pensaklaran ZVS}

Pengujian ini dilakukan untuk mengetahui proses pensaklaran ketika arus nol. Gelombang yang diamati adalah gelombang keluaran IC TL 494 dan gelombang tegangan kapasitor $\mathrm{C}_{\mathrm{r}}$. Hasil pengujian ditunjukkan pada Gambar 8.

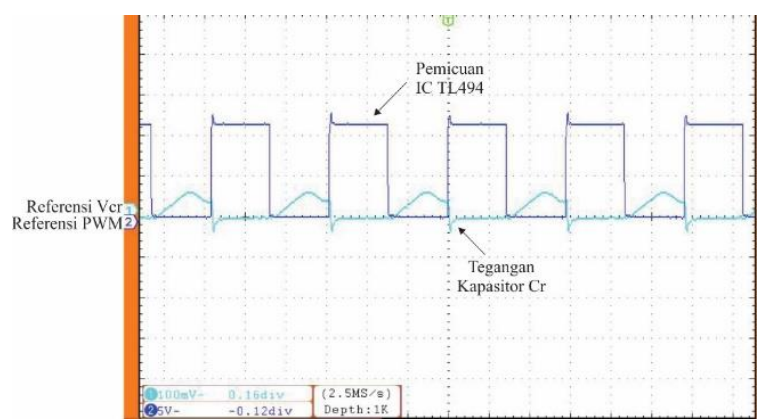

Berdasarkan Gambar 7 dapat diamati bahwa bahwa pensaklaran ZVS terjadi ketika saklar off, sedangkan ketika saklar on tidak terjadi saat tegangan nol.

\subsubsection{Pengukuran Tegangan Keluaran ZVS Buck Converter}

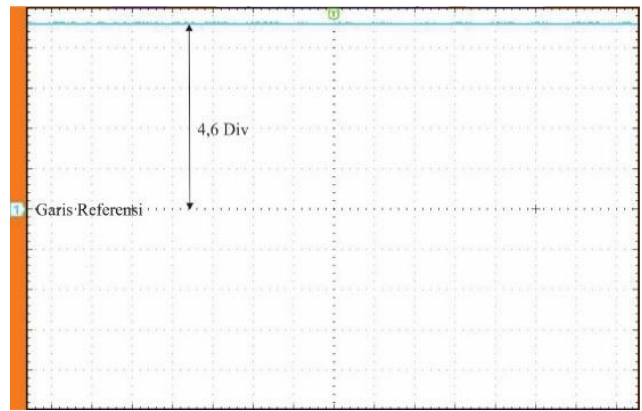

Gambar 9. Gelombang Tegangan Keluaran ZVS Buck

Gambar 9 merupakan gelombang tegangan keluaran ZVS buck converter. Hasil pengukuran tegangan keluaran dapat dilihat pada Tabel 1 sampai Tabel 4.

Tabel 1. Hasil Pengukuran Tegangan Keluaran Variasi Duty Cycle Beban Resistif $\mathrm{F}=17 \mathrm{kHz}$

\begin{tabular}{ccccccc}
\hline \multirow{2}{*}{$\begin{array}{c}\text { Duty } \\
\text { Cycle }\end{array}$} & \multicolumn{2}{c}{ R 100 $\mathbf{\Omega}$} & \multicolumn{2}{c}{ R 300 $\Omega$} & \multicolumn{2}{c}{ R 500 $\Omega$} \\
\hline 10 & 48,16 & 26,87 & 48,61 & 38,87 & 49,12 & 42,77 \\
20 & 48,09 & 30,51 & 48,58 & 40,93 & 48,50 & 43,65 \\
30 & 47,89 & 33,11 & 48,61 & 42,55 & 48,49 & 44,84 \\
40 & 47,47 & 36,47 & 48,33 & 44,54 & 48,51 & 45,76 \\
50 & 47,95 & 39,49 & 48,86 & 45,66 & 48,96 & 47,03 \\
60 & 47,82 & 42,00 & 48,82 & 46,80 & 48,97 & 47,78 \\
70 & 47,57 & 43,94 & 48,61 & 47,45 & 49,01 & 48,40 \\
80 & 47,38 & 45,95 & 48,35 & 47,79 & 48,92 & 48,64 \\
90 & 46,88 & 46,26 & 48,30 & 47,79 & 48,81 & 48,70 \\
\hline
\end{tabular}

Tabel 2. Hasil Pengukuran Tegangan Keluaran Variasi Duty Cycle Beban Motor Arus Searah F=17kHz

\begin{tabular}{ccccc}
\hline $\begin{array}{c}\text { Duty } \\
\text { cycle }\end{array}$ & \multicolumn{2}{c}{ Tanpa Blower } & \multicolumn{2}{c}{ Dengan Blower } \\
\hline 10 & 49,33 & Vout & Vin & Vout \\
20 & 49,23 & 39,97 & 47,63 & 16,65 \\
30 & 49,19 & 42,62 & 47,13 & 18,49 \\
40 & 49,27 & 44,13 & 47,05 & 20,07 \\
50 & 49,03 & 45,62 & 46,53 & 24,34 \\
60 & 49,18 & 46,26 & 45,91 & 27,56 \\
70 & 48,82 & 47,63 & 45,20 & 30,34 \\
80 & 48,53 & 47,95 & 44,52 & 32,24 \\
90 & 48,50 & 48,14 & 42,88 & 36,11 \\
\end{tabular}

Gambar 8. Gelombang Pemicuan IC TL 494 dan Tegangan Kapasitor V $\mathrm{cr}$ 
Tabel 3. Hasil Pengukuran Tegangan Keluaran Variasi Frekuensi Pensaklaran Beban Resistif $\mathbf{D}=50 \%$

\begin{tabular}{ccccccc}
\hline \multirow{2}{*}{ Frekuensi } & \multicolumn{2}{c}{ R 500 $\Omega$} & \multicolumn{2}{c}{ R 300 $\Omega$} & \multicolumn{2}{c}{ R 100 $\Omega$} \\
& Vin & Vout & Vin & Vout & Vin & Vout \\
\hline 17 & 48,96 & 47,03 & 48,66 & 45,65 & 47,95 & 39,44 \\
20 & 49,04 & 47,42 & 48,66 & 46,11 & 47,85 & 40,95 \\
25 & 48,93 & 47,67 & 48,65 & 46,67 & 48,05 & 42,50 \\
30 & 48,77 & 47,75 & 48,35 & 46,72 & 48,01 & 43,40 \\
35 & 48,70 & 47,83 & 48,75 & 46,97 & 47,96 & 44,01 \\
40 & 48,75 & 48,01 & 48,44 & 47,21 & 47,92 & 44,48 \\
45 & 48,75 & 48,14 & 48,33 & 47,19 & 47,87 & 44,84 \\
\hline
\end{tabular}

Tabel 4. Hasil Pengukuran Tegangan Keluaran Variasi Frekuensi Pensaklaran Beban Motor Arus Searah $\mathrm{D}=\mathbf{5 0 \%}$

\begin{tabular}{ccccc}
\hline $\begin{array}{c}\text { Duty } \\
\text { Cycle }\end{array}$ & \multicolumn{2}{c}{ Tanpa Blower } & \multicolumn{2}{c}{ Dengan Blower } \\
Vin (V) & Vout (V) & Vin (V) & Vout (V) \\
\hline 17 & 49,03 & 46,26 & 46,41 & 27,78 \\
20 & 48,99 & 46,99 & 46,21 & 27,84 \\
25 & 49,00 & 47,40 & 45,68 & 28,27 \\
30 & 48,70 & 47,49 & 45,22 & 29,99 \\
35 & 48,99 & 47,90 & 44,12 & 31,55 \\
40 & 49,16 & 48,21 & 44,12 & 32,55 \\
45 & 49,16 & 48,36 & 43,76 & 34,03 \\
\hline
\end{tabular}

Tabel 1 sampai Tabel 4 menunjukkan hasil pengukuran tegangan keluaran ZVS Buck Converter dengan variasi duty cycle dan frekuensi pensaklaran.

Berdasarkan Tabel 1 dan Tabel 2 disajikan grafik perbandingan antara duty cycle dengan tegangan keluaran pada Gambar 10.

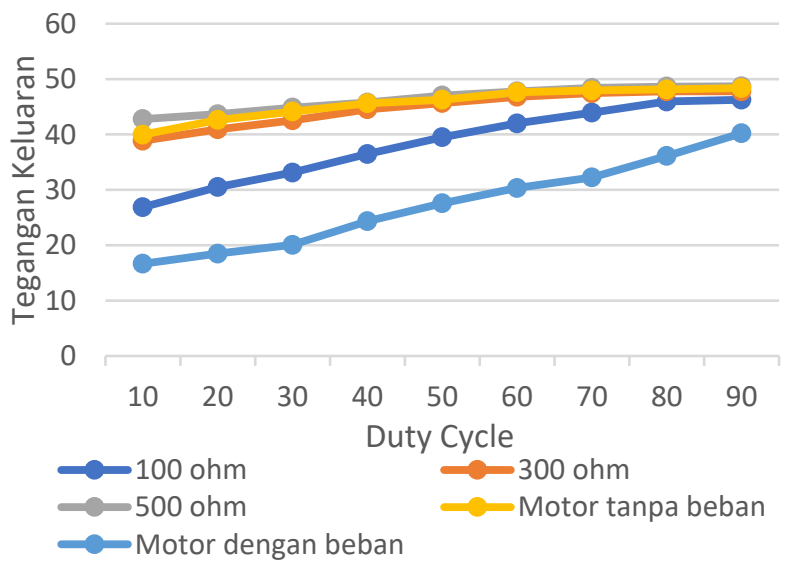

Gambar 10. Grafik Perbandingan Duty Cycle dengan Tegangan Keluaran

Gambar 10 memperlihatkan hubungan antara duty cycle dengan tegangan keluaran. Semakin besar nilai duty cycle maka nilai tegangan keluaran akan semakin besar. Variasi resistansi pembebanan memperlihatkan bahwa dengan nilai duty cycle yang sama, beban dengan nilai resistansi yang lebih besar akan menghasilkan tegangan keluaran yang lebih besar. Sedangkan pada beban motor, dengan nilai duty cycle yang sama, ketika kondisi motor tanpa beban menghasilkan tegangan keluaran yang lebih besar.

Berdasarkan Tabel 3 dan Tabel 4 dapat disajikan grafik perbandingan frekuensi pensaklaran dengan tegangan keluaran pada Gambar 11.

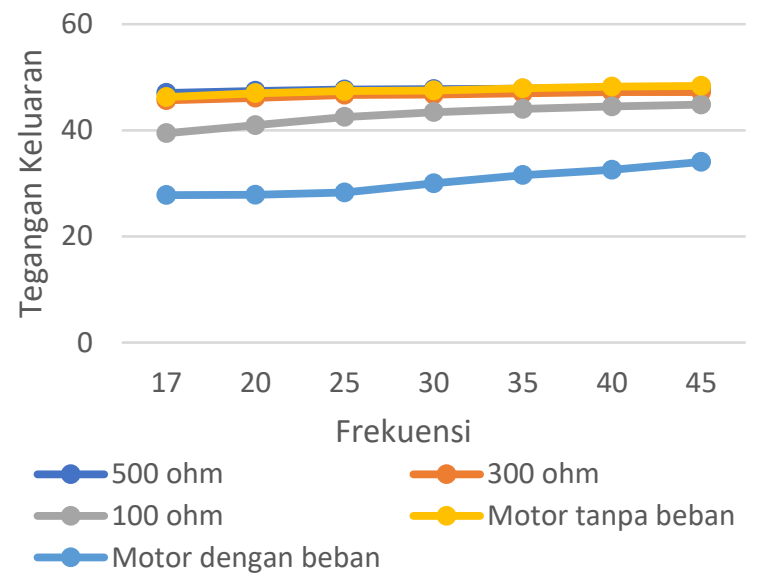

Gambar 11. Perbandingan Frekuensi Pensaklaran dengan Tegangan Keluaran

Gambar 11 menunjukkan variasi resistansi pembebanan memperlihatkan bahwa dengan nilai frekuensi pensaklaran yang sama, beban dengan nilai resistansi yang lebih besar akan menghasilkan tegangan keluaran yang lebih besar. Sedangkan pada beban motor, dengan nilai frekuensi yang sama, ketika kondisi motor tanpa beban menghasilkan tegangan keluaran yang lebih besar.

\subsubsection{Pengukuran Arus dan Perhitungan Daya ZVS Buck Converter}

Pengukuran ini dilakukan pada arus keluaran rangkaian ZVS Buck Converter dengan menggunakan beban resistor dan motor arus searah. Variasi yang dilakukan yaitu variasi duty cycle.

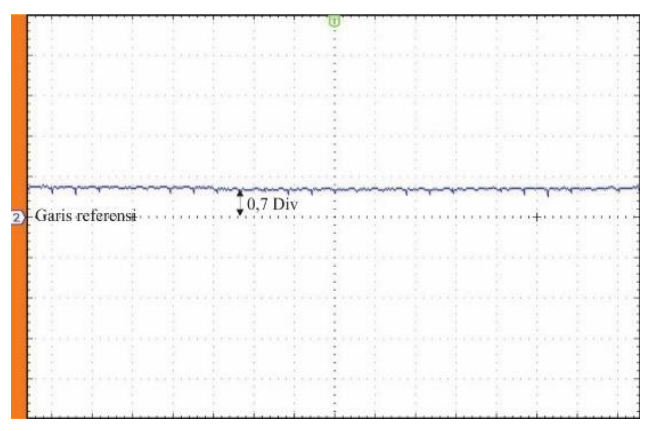

Gambar 12. Gelombang Arus Keluaran ZVS Buck Converter 
Gambar 12 merupakan gambar arus keluaran ZVS buck converter.Perhitungan daya dapat dilakukan dengan menggunakan Persamaan 4.

$P=V \times I$

Hasil pengukuran dan perhitungan daya disajikan pada Tabel 5 sampai dengan Tabel 8.

Tabel 5. Hasil Pengukuran Arus Masukan dan Perhitungan Daya Variasi Duty Cycle Beban Resistif F=17khz

\begin{tabular}{ccccccc}
\hline $\begin{array}{c}\text { Duty } \\
\text { Cycle }\end{array}$ & \multicolumn{2}{c}{$\mathbf{5 0 0 \Omega}$} & \multicolumn{2}{c}{$300 \Omega$} & \multicolumn{2}{c}{$100 \Omega$} \\
\hline $\mathbf{1 0}$ & lin & Pin & lin & Pin & lin & Pin \\
$\mathbf{2 0}$ & 0,29 & 13,97 & 0,15 & 7,29 & 0,10 & 4,91 \\
$\mathbf{3 0}$ & 0,33 & 15,87 & 0,15 & 7,29 & 0,10 & 4,85 \\
$\mathbf{4 0}$ & 0,39 & 18,51 & 0,15 & 7,29 & 0,11 & 5,33 \\
$\mathbf{5 0}$ & 0,45 & 21,58 & 0,16 & 7,73 & 0,10 & 4,85 \\
$\mathbf{6 0}$ & 0,45 & 21,52 & 0,16 & 7,82 & 0,11 & 5,39 \\
$\mathbf{7 0}$ & 0,48 & 22,83 & 0,16 & 7,78 & 0,11 & 5,39 \\
$\mathbf{8 0}$ & 0,48 & 22,74 & 0,16 & 7,74 & 0,12 & 5,87 \\
$\mathbf{9 0}$ & 0,51 & 23,91 & 0,15 & 7,25 & 0,12 & 5,86 \\
\hline
\end{tabular}

Tabel 6. Hasil Pengukuran Arus Keluaran dan Perhitungan Daya Variasi Duty Cycle Beban Resistif F=17kHz

\begin{tabular}{ccccccc}
\hline \multirow{2}{*}{$\begin{array}{c}\text { Duty } \\
\text { Cycle }\end{array}$} & \multicolumn{2}{c}{$\mathbf{5 0 0 \Omega}$} & \multicolumn{2}{c}{$300 \Omega$} & \multicolumn{2}{c}{$100 \Omega$} \\
\hline 10 & lout & Pout & lout & Pout & lout & Pout \\
\hline 20 & 0,28 & 7,52 & 0,14 & 5,44 & 0,08 & 3,42 \\
30 & 0,32 & 9,76 & 0,13 & 5,32 & 0,09 & 3,93 \\
40 & 0,38 & 10,60 & 0,15 & 6,38 & 0,10 & 4,48 \\
50 & 0,45 & 17,76 & 0,15 & 6,68 & 0,10 & 4,58 \\
60 & 0,45 & 18,90 & 0,15 & 7,02 & 0,10 & 4,78 \\
70 & 0,47 & 20,65 & 0,16 & 7,59 & 0,10 & 4,84 \\
80 & 0,48 & 22,06 & 0,16 & 7,65 & 0,11 & 5,35 \\
90 & 0,51 & 23,59 & 0,15 & 7,17 & 0,12 & 5,84 \\
\hline
\end{tabular}

Tabel 7. Hasil Pengukuran Arus Masukan dan Perhitungan Daya Variasi Duty Cycle Beban Motor Arus Searah $\mathbf{F}=17 \mathbf{k H z}$

\begin{tabular}{ccccccc}
\hline \multirow{2}{*}{$\begin{array}{c}\text { Duty } \\
\text { Cycle }\end{array}$} & \multicolumn{2}{c}{$\begin{array}{c}\text { Motor Tanpa } \\
\text { Beban }\end{array}$} & \multicolumn{4}{c}{$\begin{array}{c}\text { Motor dengan } \\
\text { Blower }\end{array}$} \\
& Vin & Iin & Pin & Vin & Iin & Pin \\
\hline 10 & 49,33 & 0,11 & 5,43 & 47,63 & 0,43 & 20,48 \\
20 & 49,23 & 0,11 & 5,42 & 47,13 & 0,51 & 24,04 \\
30 & 49,19 & 0,12 & 5,90 & 47,05 & 0,60 & 28,23 \\
40 & 49,27 & 0,12 & 5,91 & 46,53 & 0,83 & 38,62 \\
50 & 49,03 & 0,12 & 5,88 & 45,91 & 1,02 & 46,83 \\
60 & 49,18 & 0,11 & 5,41 & 45,20 & 1,26 & 56,95 \\
70 & 48,82 & 0,12 & 5,86 & 44,52 & 1,45 & 64,55 \\
80 & 48,53 & 0,11 & 5,34 & 42,88 & 2,14 & 91,76 \\
90 & 48,50 & 0,11 & 5,34 & 42,58 & 2,57 & 109,43 \\
\hline
\end{tabular}

Tabel 8. Hasil Pengukuran Arus Keluaran dan Perhitungan Daya Variasi Duty Cycle Beban Motor Arus Searah $F=17 \mathrm{kHz}$

\begin{tabular}{ccccccc}
\hline \multirow{2}{*}{$\begin{array}{c}\text { Duty } \\
\text { Cycle }\end{array}$} & \multicolumn{3}{c}{ Motor Tanpa Beban } & \multicolumn{3}{c}{ Motor dengan Blower } \\
\hline 10 & 49,33 & lin & Pin & Vin & lin & Pin \\
\hline 20 & 49,11 & 5,43 & 47,63 & 0,43 & 20,48 \\
30 & 49,19 & 0,11 & 5,42 & 47,13 & 0,51 & 24,04 \\
40 & 49,27 & 0,12 & 5,90 & 47,05 & 0,60 & 28,23 \\
50 & 49,03 & 0,12 & 5,91 & 46,53 & 0,83 & 38,62 \\
60 & 49,18 & 0,11 & 5,41 & 45,20 & 1,26 & 56,95 \\
70 & 48,82 & 0,12 & 5,86 & 44,52 & 1,45 & 64,55 \\
80 & 48,53 & 0,11 & 5,34 & 42,88 & 2,14 & 91,76 \\
90 & 48,50 & 0,11 & 5,34 & 42,58 & 2,57 & 109,43 \\
\hline
\end{tabular}

Berdasarkan Tabel 5 sampai Tabel 8, maka akan dapat dihitung nilai efisiensi pada masing-masing variasi beban dengan Persamaan 5.

efisiensi $(\%)=\frac{P_{\text {out }}}{P_{\text {in }}} \times 100 \%$

Berdasarkan Persamaan 5, maka akan didapat hasil perhitungan efisiensi pada Tabel 9.

Tabel 9. Hasil Perhitungan Efisiensi Variasi Duty Cycle Beban Motor Arus Searah F=17kHz

\begin{tabular}{cccccc}
\hline $\begin{array}{c}\text { Duty } \\
\text { Cycle }\end{array}$ & $\mathbf{1 0 0} \boldsymbol{\Omega}$ & $\mathbf{3 0 0} \boldsymbol{\Omega}$ & $\mathbf{5 0 0} \boldsymbol{\Omega}$ & $\begin{array}{c}\text { Motor } \\
\text { Tanpa } \\
\text { Beban }\end{array}$ & $\begin{array}{c}\text { Motor dengan } \\
\text { Beban }\end{array}$ \\
\hline 10 & 53,87 & 74,63 & 69,66 & 73,66 & 52,84 \\
20 & 61,52 & 73,02 & 81,00 & 78,70 & 57,69 \\
30 & 67,04 & 87,53 & 84,07 & 74,76 & 61,85 \\
40 & 74,86 & 86,40 & 94,33 & 77,16 & 74,37 \\
50 & 82,36 & 87,61 & 87,33 & 78,63 & 82,98 \\
60 & 87,83 & 89,87 & 97,57 & 88,04 & 88,97 \\
70 & 90,44 & 97,61 & 89,78 & 81,85 & 87,90 \\
80 & 96,98 & 98,84 & 91,14 & 81,16 & 87,75 \\
90 & 98,68 & 98,94 & 99,77 & 90,67 & 94,83 \\
\hline
\end{tabular}

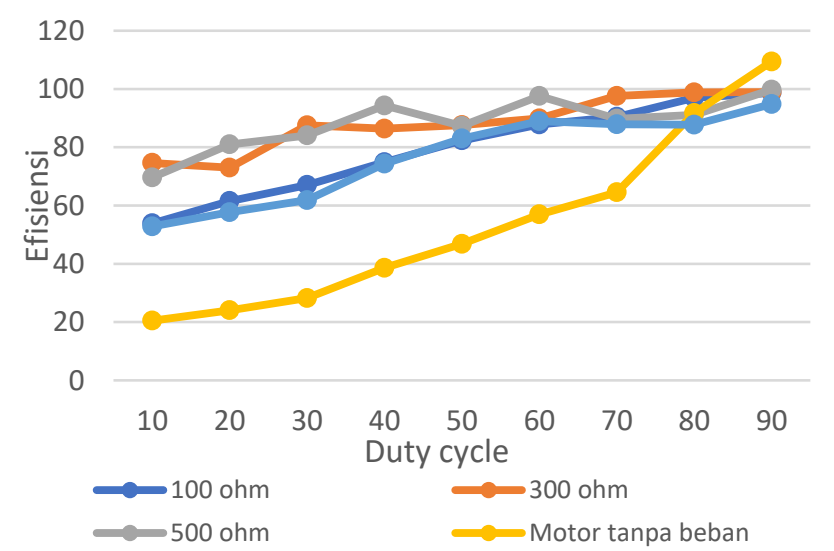

Gambar 13. Grafik Perbandingan Duty Cycle Dengan Efisiensi 
Gambar 13 memperlihatkan bahwa nilai efisiensi cenderung akan mengalami kenaikan ketika nilai duty cycle dinaikkan. Pada masing-masing variasi beban efisiensi paling tinggi terjadi ketika duty cycle bernilai $90 \%$.

\subsubsection{Pengaruh Pengaturan Duty Cycle dan Frekuensi pada Kecepatan Motor Arus Searah}

Pengujian variasi duty cycle dan frekuensi mempengaruhi tegangan keluaran dari ZVS buck konverter. Hal ini berdampak pada kecepatan motor. Hasil pengujian variasi duty cycle dan frekuensi terhadap kecepatan putar motor seperti terlihat pada Tabel 4.10 dan Tabel 4.11.

Tabel 10. Hubungan antara Duty Cycle dengan Kecepatan Motor

\begin{tabular}{ccccc}
\hline $\begin{array}{c}\text { Duty } \\
\text { Cycle }\end{array}$ & \multicolumn{2}{c}{ Tanpa Blower } & \multicolumn{2}{c}{ Dengan Blower } \\
Vout & RPM & Vout & RPM \\
\hline 10 & 39,97 & 3447 & 16,65 & 1220 \\
20 & 42,62 & 3673 & 18,49 & 1351 \\
30 & 44,13 & 3806 & 20,07 & 1460 \\
40 & 45,62 & 3934 & 24,34 & 1733 \\
50 & 46,26 & 4021 & 27,56 & 1937 \\
60 & 47,63 & 4073 & 30,34 & 2123 \\
70 & 47,95 & 4134 & 32,24 & 2229 \\
80 & 48,14 & 4156 & 36,11 & 2528 \\
90 & 48,37 & 4174 & 40,22 & 2747 \\
\hline
\end{tabular}

Tabel 11. Hubungan antara Frekuensi dengan Kecepatan Motor

\begin{tabular}{ccccc}
\hline $\begin{array}{c}\text { Frekuensi } \\
\text { (kHz) }\end{array}$ & \multicolumn{2}{c}{ Tanpa Blower } & \multicolumn{2}{c}{ Dengan Blower } \\
Vout & RPM & Vout & RPM \\
\hline 17 & 46,26 & 4021 & 27,78 & 1981 \\
20 & 46,99 & 4028 & 27,84 & 1984 \\
25 & 47,40 & 4073 & 28,27 & 2034 \\
30 & 47,49 & 4105 & 29,99 & 2120 \\
35 & 47,90 & 4125 & 31,55 & 2231 \\
40 & 48,21 & 4177 & 32,55 & 2266 \\
45 & 48,36 & 4189 & 34,03 & 2360 \\
\hline
\end{tabular}

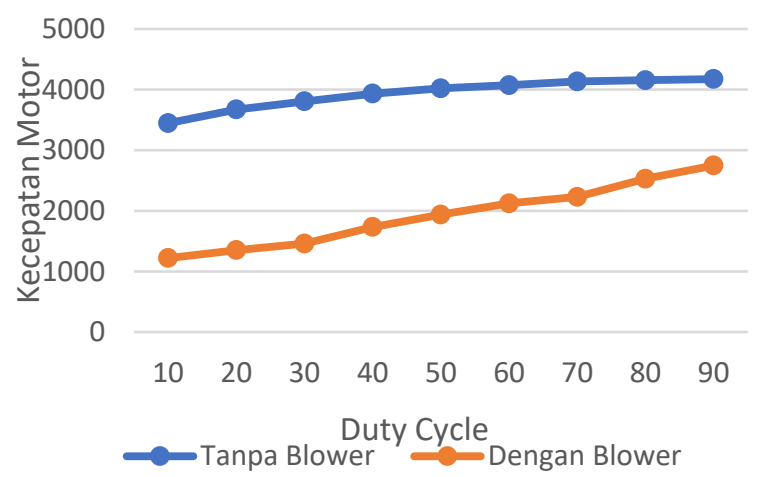

Gambar 14. Grafik Perbandingan Duty Cycle dengan Efisiensi

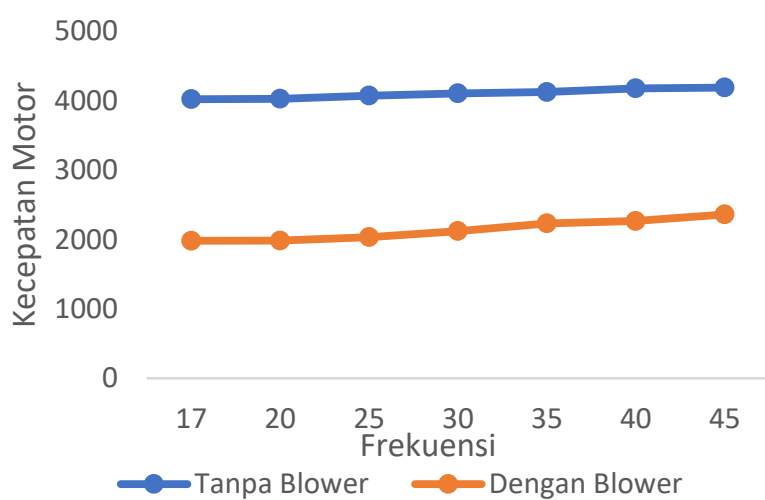

Gambar 15. Grafik Perbandingan Frekuensi dengan Efisiensi

Dari Gambar 4.14 dan 4.15 terlihat bahwa dengan naiknya duty cycle dan frekuensi akan diikuti dengan kecepatan putar motor. Hal ini karena dipengaruhi kenaikan yang terjadi pada tegangan keluaran. Kecepatan putar motor saat kondisi berbeban telah mencapai kecepatan yang tertera pada datasheet. Kecepatan putar motor saat berbeban blower tidak mecapai kecepatan putar. Hal ini dikarenakan motor mengalami beban lebih atau overload.

\section{Kesimpulan}

Berdasarkan perancangan, pengujian dan analisa yang Berdasarkan hasil pengujian rangkaian ZVS buck konverter mampu melakukan proses pensaklaran saat tegangan nol ketika saklar off. Ketika saklar kondisi on pensaklaran tidak terjadi saat arus nol karena adanya efek parasitik di dalam rangkaian konverter arus searah. Kenaikan level tegangan pada ZVS buck konverter bergantung pada duty cycle dan jenis beban yang diberikan pada rangkaian. Pada pengujian tegangan keluaran ZVS buck konverter dengan variasi duty cycle nilai tegangan keluaran akan naik seiring dengan kenaikan nilai duty cycle. Nilai tegangan terendah terjadi saat pembebanan motor arus searah dengan blower yang bernilai 16,65 Volt saat duty cycle $10 \%$. Sedangkan nilai tegangan tertinggi terjadi saat pembebanan resistor $500 \Omega$ yang bernilai 48,81 Volt saat duty cycle 90\%. Pada pengujian tegangan keluaran ZVS buck konverter dengan variasi frekuensi pensaklaran, tegangan keluaran akan naik seiring dengan kenaikan frekuensi pensaklaran. Nilai tegangan keluaran tertinggi sebesar 48,36 Volt untuk beban motor arus searah tanpa blower saat frekuensi bernilai $45 \mathrm{kHz}$. Sedangkan nilai tegangan terendah terjadi saat pembebanan motor arus searah dengan blower resistor yang bernilai 27,78 Volt saat frekuensi bernilai $17 \mathrm{kHz}$. Daya maksimal keluaran hasil perhitungan terjadi saat pembebanan motor arus searah dengan blower sebesar 103,77 Watt. Nilai efisiensi terendah terjadi saat pembebanan motor arus searah dengan blower yang bernilai $52,84 \%$ saat duty cycle $10 \%$. Nilai efisiensi 
tertinggi terjadi saat pembebanan resistor $500 \Omega$ yang bernilai $99,77 \%$ saat duty cycle $90 \%$. Nilai efisiensi ratarata dari ZVS buck konverter pada saat beban resistor adalah sebesar $85,28 \%$ dan saat beban motor adalah $78,55 \%$. Rata-rata efisiensi keseluruhan adalah $82,59 \%$.

Penelitian ini dapat dikembangkan dengan menggunakan metode soft switching yang lain yaitu pensaklaran arus nol (zero current switching). Rangkaian kontrol IC TL494 dapat digantikan dengan menggunakan mikrokontroler. Pengujian dapat dikembangkan untuk pembebanan jenis motor arus searah jenis eksitasi yang lain.

\section{Referensi}

[1]. K. A. W. Hudaya, A. Warsito, and M. Facta, "Pembuatan Penyearah Terkontrol Penuh Satu Fasa Sebagai Pengemudi Motor Dc 3 Hp," Undergrad. thesis, Jur. Tek. Elektro Fak. Tek. Undip., pp. 1-6, 2002.
[2]. P. Tawakal, A. Nugroho, and M. Facta, "Penyearah Terkontrol Penggerak Motor Arus Searah Pada Purwarupa Konveyor," Undergrad. thesis, Jur. Tek. Elektro Fak. Tek. Undip., 2016.

[3]. C. Ibrahim, T. Sukmadi, and A. Nugroho, "Perancangan Pengontrolan Motor Dc Menggunakan Dc - Dc Konverter Class C Mode Motoring Dan Regenerative Breaking Untuk Simulasi Kendaraan Listrik."

[4]. M. A. Wibowo, I. A. Warsito, D. Ir, and T. Sukmadi, "Perancangan Rangkaian H-Bridge Chopper Untuk Simulasi Kendaraan Listrik Dengan Pemicuan PWM Analog dan Digital," pp. 3-10.

[5]. D. W. Hart, Power Electronics. New York: McGrawHil, 2011.

[6]. International Rectifier, "IRFP260N," pp. 1-9.

[7]. T. Instruments, "TL494 Pulse-Width-Modulation Control Circuits," 2017.

[8]. O. Semiconductor, "MUR1560,” Power, pp. 1-7, 1996. 